\title{
Hypertension in adult polycystic kidney disease: a narrative review
}

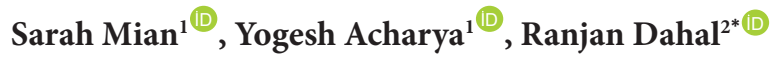 \\ ${ }^{1}$ Avalon University School of Medicine, Curacao, Netherlands Antilles \\ ${ }^{2}$ Saint Peter's University Hospital, New Jersey, USA
}

\section{A R T I C L E I N F 0}

Article Type:

Review

\section{Article History:}

Received: 10 November 2018

Accepted: 2 January 2019

Published online: 9 January 2019

\section{Keywords:}

Adult polycystic kidney disease, Hypertension, Antihypertensive agents, Prevention and control, Reninangiotensin-aldosterone system, End stage renal disease, Glomerular filtration rate, Chronic kidney disease

\begin{abstract}
A B S T R A C T
Autosomal dominant polycystic kidney disease (ADPKD) is an inherited renal disorder that impacts approximately 12 million worldwide. It is characterized by bilateral kidney enlargement and cystic growth. Hypertension (HTN) is a focal point in the management of ADPKD and is linked to a faster progression to end stage renal disease. Current novel therapies have proven to reduce the progression of renal damage. The ideal goal is to minimize risk through preventative studies and pharmacology to further increase life expectancy and quality. The purpose of this article is to highlight the importance of blood pressure management in ADPKD and review current literature to determine the most effective preventative pharmacotherapy.
\end{abstract}

Implication for health policy/practice/research/medical education:

1. Hypertension (HTN) is an important risk factor for progressive renal and extra-renal complications in adult polycystic kidney disease (ADPKD).

2. Ambulatory blood pressure monitoring is important as complications like left ventricular hypertrophy (LVH) can manifest even before the diagnosis of HTN.

3. HTN, if not treated early, will potentially lead to faster glomerular filtration rate (GFR) decline and end stage renal disease. 4. Although no overall benefit of one antihypertensive over other is established to prevent decline in GFR, angiotensin-converting enzyme inhibitor (ACE-I)/ angiotensin receptor blocker (ARB) is recommended at present.

5. There is a strong need for standardized guidelines for management of HTN in ADPKD.

Please cite this paper as: Mian S, Acharya Y, Dahal R. Hypertension in adult polycystic kidney disease: a narrative review.

J Renal Inj Prev. 2019;8(2):122-126. doi: 10.15171/jrip.2019.23.

\section{Introduction}

Autosomal dominant polycystic kidney disease (ADPKD) is an aggressive hereditary renal disorder that affects nearly 1:1000 individuals (1). It is detected by small, fluid-filled cysts in the kidney, which can result in end-stage renal disease (ESRD). Hypertension (HTN) develops early in the course, which is a major risk factor for cardiovascular disease and the most common cause of death (2).

\section{Materials and Methods}

We aim to discuss HTN in ADPKD, analyze its determinants, and review management strategies in various patient groups. We systematically reviewed studies from PubMed database. A non-specific combination of keywords was used: "ADPKD", "Hypertension", "Management", and "Prevention." All the relevant studies were extracted, analyzed, and reviewed as per the objectives.

\section{Hypertension in ADPKD}

HTN is evident in $50 \%-70 \%$ of the patients (3). It is a common clinical finding that can reflect as early as 30 years of age (4), occurring prior to any significant reduction in glomerular filtration rate (GFR). Interestingly, left ventricular hypertrophy (LVH) may be evident in some patients even before HTN is diagnosed (5). Therefore, 
these patients may benefit from ambulatory blood pressure (BP) monitoring for early detection and proper management (6).

HTN in ADPKD is attributed to progressive cystic enlargement, which is an important risk factor for the development of ESRD (Figure 1). Patients can have a higher prevalence of targeted organ damage associated with renal function. Proliferative and expansive renal cysts activate the renin-angiotensin-aldosterone system (RAAS), causing the vicious cycle of cyst expansion and HTN, eventually leading to kidney injury and ESRD (7).

\section{Epidemiology}

ADPKD is a genetic disease and mutations in the PKD1 (chromosome 16p13.3) and PKD2 genes (chromosome $4 \mathrm{q} 21$ ) are the chief determinants (8). Symptoms can differ, yet HTN occurs in more than half of the patients prior to the functional impairment (9). HTN can serve as an early screening tool in preventing irreversible renal damage and adverse cardiovascular events.

\section{Pathophysiology}

It is imperative to understand the pathophysiology of HTN in ADPKD to halt the renal disease progression and other complications, and manage accordingly. The clearcut mechanism for cyst formation and expansion is not well understood yet, and to entail it in detail is beyond the scope of this article.

The PKD1 and PKD2 genes encode transmembrane proteins polycystin 1 (PC1) and polycystin 2 (PC2) respectively. One hypothesis of cyst formation is $\mathrm{PC1}-$ PC2 cilia-dependent cyst activation (CDCA) signaling mechanism. CDCA pathway is maintained in resting state physiologically by PC1-PC2 complex, which is expressed in cilia. Loss of PC1 from PC1-PC2 complex cause activation of CDCA pathway which will change the morphology of cells, remodel the kidney tissues and promote cyst growth. Normal renal parenchyma will eventually be replaced by the cyst, potentially causing renal impairment and ESRD (10). Nevertheless, severity is directly related to the disease duration (11).

Many theories have been postulated for the probable cause of HTN in ADPKD, out of which activation of

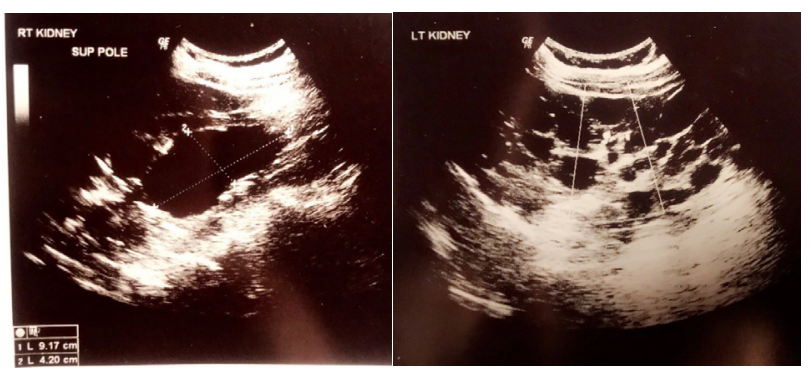

Figure 1. Ultrasound Images Showing Multiple Cysts in Both the Kidneys.
RAAS is the most convincing (Figure 2). Patients are found to have increased plasma renin and aldosterone (12). There is also evidence of juxtaglomerular apparatus (JGA) hyperplasia and local production of RAAS (13). Activation of RAAS can cause sympathetic stimulation and HTN. Some studies suggest cyst enlargement and hypoxic ischemia, as the cause of increased erythropoietin production (14) and tubular sodium reabsorption (15), both contributing to HTN. Low nitric oxide levels (9) in ADPKD also affect the vasodilatory response in kidneys. Volume expansion due to an increased aldosterone and vasopressin can be an alternative mechanism.

\section{Complications}

HTN is associated with kidney enlargement and ESRD. Uncontrolled BP can lead to a series of fatal events with an increased frequency of both intracranial aneurysms and arterial HTN (2). Intracranial aneurysms are the most dreaded complications with prevalence ranging from $4 \%-41.2 \%$ (16). It also causes cysts to grow bilaterally in kidneys and systematically affect other cells in the body, including heart valves, liver and intestinal tissue. Growing cysts eventually replace the healthy normal kidney, resulting in failure. At times, cardiovascular complications like endothelial damage, diastolic flow dysfunction, and vascular wall thickening are manifested even in normotensive patients with ADPKD prior to HTN and renal impairment (17). Early occurrence of cardiovascular complications emphasizes a definitive need to control BP for further risk stratification as well as reduction.

\section{Management}

Effective and aggressive BP control decreases the mortality in ADPKD patients (18). Based on these facts, the management of progressive disease relies heavily on early detection and control of BP. The goals of antihypertensive agents are to decrease total kidney volume (TKV), block the RAAS, and delay the progression of renal failure (8). Based on pathophysiological considerations, RAAS inhibitors, including angiotensin-converting enzyme

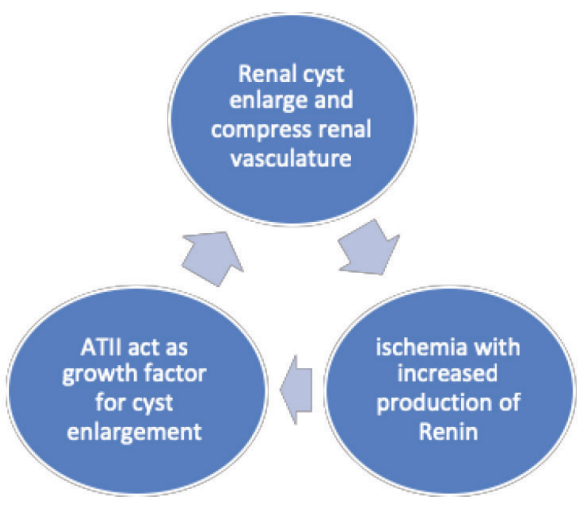

Figure 2. Picture showing vicious cycle of cyst expansion and subsequent activation of RAAS. (RAAS- renin angiotensin aldosterone system, ATII- angiotensin II). 
inhibitors (ACE-I), angiotensin II receptor blockers (ARBs), are known to be the first choice in preventative therapy and management as well (19). They cause regression of cyst growth, decrease total kidney volume, and play a vital role in risk reduction (9).

HALT-PKD (20), the largest study till date for ADPKD, showed that intensive BP control could decrease kidney volume enlargement, left-ventricular mass index, urinary albumin excretion, but estimated GFR (Table 1). Mitobe et al (21), Nutahara et al (22) and Ecder et al (23) demonstrated slower GFR decline with ACE-I when compared with calcium channel blockers (CCB) and diuretics. Aggressive $\mathrm{BP}$ regulation and maintaining $<140 / 90 \mathrm{~mm} \mathrm{Hg}$ is found to be effective, as it is correlated with a slower progression to ESRD. BP $<135 / 85 \mathrm{~mm} \mathrm{Hg}$ is recommended in patients with evidence of microalbuminuria or LVH (24). Renal ultrasound screening of hypertensive patients serves as an important tool to monitor disease progression (25). Similarly, general instruction of limiting salt and caffeine intake, exercising, and restraining from smoking will

Table 1. Recent studies that discusses the management of HTN in ADPKD

\begin{tabular}{|c|c|c|c|c|}
\hline Authors & Type of study & Objective & Sample Size & Result \\
\hline $\begin{array}{l}\text { Schrier et al } \\
(20)\end{array}$ & $\begin{array}{l}\text { Double-blind, } \\
\text { placebo- } \\
\text { controlled trial }\end{array}$ & $\begin{array}{l}\text { To compare lisinopril with lisinopril and } \\
\text { telmisartan in regard to safety and efficacy in } \\
\text { controlling BP in ADPKD. } \\
\text { To compare standard against low BP in patients } \\
\text { aged } 15-49 \text { years with GFR }>60 \mathrm{~mL} / \mathrm{min} / 1.73 \mathrm{~m}^{2} \\
\text { BSA }\end{array}$ & 558 & $\begin{array}{l}\text { Early ADPKD- lisinopril and } \\
\text { telmisartan was not associated } \\
\text { with significant reduction in kidney } \\
\text { volume progression as compared with } \\
\text { lisinopril alone. } \\
\text { Intensive BP control- decreases kidney } \\
\text { volume enlargement, left-ventricular } \\
\text { mass index and urinary albumin } \\
\text { excretion, but estimated GFR. }\end{array}$ \\
\hline $\begin{array}{l}\text { Torres et al } \\
(35)\end{array}$ & $\begin{array}{l}\text { Double-blind } \\
\text { placebo- } \\
\text { controlled trial }\end{array}$ & $\begin{array}{l}\text { To demonstrate efficacy of lisinopril alone } \\
\text { or lisinopril and telmisartan in decreasing } \\
\text { progression of disease in moderately advanced } \\
\text { ADPKD. }\end{array}$ & 486 & $\begin{array}{l}\text { Lisinopril alone maintained good BP } \\
\text { control in ADPKD and with CKD-III. } \\
\text { Addition of telmisartan with lisinopril } \\
\text { did not prevent estimated reduction } \\
\text { in GFR. }\end{array}$ \\
\hline $\begin{array}{l}\text { Mitobe et al } \\
(21)\end{array}$ & $\begin{array}{l}\text { Retrospective } \\
\text { study }\end{array}$ & $\begin{array}{l}\text { To access the effectiveness of CCB and/or RAAS } \\
\text { inhibitors on changes in the estimated GFR in } \\
\text { patients with ADPKD. }\end{array}$ & 31 & $\begin{array}{l}\text { It is better to avoid CCB in ADPKD } \\
\text { patients to achieve renal protection } \\
\text { unless warranted for resistant HTN. }\end{array}$ \\
\hline $\begin{array}{l}\text { Zeltner et al } \\
(36)\end{array}$ & $\begin{array}{l}\text { Prospective } \\
\text { randomized } \\
\text { double-blind } \\
\text { study }\end{array}$ & $\begin{array}{l}\text { To compare ramipril and metoprolol as first line } \\
\text { management choice in hypertensive patients } \\
\text { with ADPKD. }\end{array}$ & 46 & $\begin{array}{l}\text { No alterations in renal function } \\
\text { or proteinuria with ramipril or } \\
\text { metoprolol. But rigorous BP control } \\
\text { slowed the progression of cardiac and } \\
\text { renal damage. }\end{array}$ \\
\hline Jafar et al (37) & Meta-analysis & $\begin{array}{l}\text { To compare efficacy of antihypertensive agents } \\
\text { (with and without ACE-I) in controlling renal } \\
\text { disease progression in PKD }\end{array}$ & 142 & $\begin{array}{l}\text { ACE-I reduced proteinuria in } \\
\text { advanced PKD. But the role of ACE-I to } \\
\text { decrease renal disease progression is } \\
\text { inconclusive. }\end{array}$ \\
\hline $\begin{array}{l}\text { Nutahara et al } \\
(22)\end{array}$ & $\begin{array}{l}\text { Randomized } \\
\text { clinical trial }\end{array}$ & $\begin{array}{l}\text { To compare the effect of } C C B \text { and } A R B \text { on } B P \text { and } \\
\text { renal function in patients with ADPKD and HTN. }\end{array}$ & 49 & $\begin{array}{l}\text { Better renal protective effect and } \\
\text { decreased albumin excretion of ARB } \\
\text { over CCB. }\end{array}$ \\
\hline $\begin{array}{l}\text { van Dijk et al } \\
\text { (38) }\end{array}$ & $\begin{array}{l}\text { Randomized } \\
\text { double-blind } \\
\text { placebo- } \\
\text { controlled trial }\end{array}$ & $\begin{array}{l}\text { To investigate the renoprotective effect of } \\
\text { enalapril in ADPKD }\end{array}$ & 89 & $\begin{array}{l}\text { No beneficial effect of ACE inhibition } \\
\text { on renal function decline. } \\
\text { Loss in renal function was similar in } \\
\text { enalapril and atenolol groups. }\end{array}$ \\
\hline $\begin{array}{l}\text { Ecder et al } \\
\text { (23) }\end{array}$ & $\begin{array}{l}\text { Prospective } \\
\text { non-randomized } \\
\text { study }\end{array}$ & $\begin{array}{l}\text { To investigate the renoprotective effect of } \\
\text { diuretics against ACE-I in hypertensive ADPKD } \\
\text { patients with similar kidney functions. }\end{array}$ & 33 & $\begin{array}{l}\text { ACE-I decreased rate of decline in } \\
\text { GFR and urinary protein excretion in } \\
\text { comparison to diuretics. }\end{array}$ \\
\hline $\begin{array}{l}\text { Ecder et al } \\
\text { (39) }\end{array}$ & $\begin{array}{l}\text { Prospective } \\
\text { randomized } \\
\text { study }\end{array}$ & $\begin{array}{l}\text { To compare the renoprotective effects of CCB } \\
\text { (amlodipine) and ACE-I (enalapril) hypertensive } \\
\text { patients with ADPKD. }\end{array}$ & 24 & $\begin{array}{l}\text { After } 5 \text { years, there was no visible } \\
\text { difference in renal function between } \\
\text { enalapril and amlodipine. } \\
\text { Control of HTN slows the onset of } \\
\text { ESRD for more than } 10 \text { years. }\end{array}$ \\
\hline
\end{tabular}

Abbreviations: ADPKD: Adult polycystic kidney disease, BP: Blood pressure, GFR: Glomerular filtration rate, CKD: Chronic kidney disease, CCB: Calcium channel blockers, RAAS: Renin angiotensin aldosterone system, ACE-I: Angiotensin converting enzyme inhibitors, ARB: Angiotensin receptors blockers, PKD: Polycystic kidney disease, ESRD: End stage renal disease. 
certainly aid in prophylactic therapy (26).

\section{Recent advancements}

Endothelin is a receptor protein. Its over expression is associated with HTN and heart disease. Serum endothelin-1 levels were higher in patients with ADPKD compared to other hypertensive/normotensive patients (27). It was found in the epithelial layer and renal cyst fluid $(28,29)$. A clinical trial conducted by Kocyigit et al $(30)$ with 138 patients determined the trends of endothelin-1 in disease progression. Results indicated that elevated serum levels were strongly associated with HTN. Similarly, patients with chronic kidney disease (CKD) followed a trend of increased endothelin-1 levels and TKV, with decreasing GFR. Therefore, endothelin can possibly serve as an early biomarker to detect HTN in ADPKD and there is a need to establish its role with conclusive studies.

\section{Discussion}

$\mathrm{HTN}$ is a cardinal feature in aggressive CKD; however, its onset and pathophysiology in ADPKD is unique. The aforementioned review of various clinical studies regarding the pharmacological maintenance of HTN reveals the significance of maintaining $\mathrm{BP}$ in order to effectively decrease TKV, reverse LVH mass index, and reduce urinary albumin excretion. Management is critical in slowing the progression of the disease and also decreasing cardiovascular risks.

Although there are no consensuses regarding the type of antihypertensive therapy in $\mathrm{ADPKD}$, most studies promote the use of ACE-I or ARBs as appropriate preventive or management agents. A pronounced decrease in renal vascular resistance was noted after their administration compared to essential antihypertensive agents (31). ACE-I prevent constriction of renal blood vessels, lower $\mathrm{BP}$, and reduce urinary albumin excretion and afterload (32). At present, they can be considered as the first line antihypertensive therapy because they offer effective and safe management of HTN (33). ARBs serve an important role in patients with adverse reactions to ACE-I, such as angioedema and can be used as an alternative to ACE-I. Both the agents decrease the BP and thus delay the progression of the renal disease.

In summary, inhibition of the RAAS with ACE-I or ARB allows for the most targeted, effective, and safe treatment of HTN in ADPKD. But evidences regarding superior efficacy and safety of RAAS blockers over other antihypertensive drugs, particularly in terms of GFR decline and TKV growth, are still not adequate (34). Beyond doubt, the general consensuses establish the critical role of antihypertensive therapy in the management ADPKD; but the overall treatment guideline has not been established. Questions still remain regarding the optimal treatment, yet current novel methods continue to decrease the morbidity and mortality through symptomatic management.

\section{Conclusion}

HTN is an important risk factor for renal disease and cardiovascular morbidity in ADPKD. Existing evidence justifies the need for early screening and management. ACE-I/ARB is preferred over other antihypertensive agents at present. Optimal BP control decreases progression of renal failure as well as extra renal complications. It is important to establish uniform guidelines to manage HTN as standard guidelines is lacking.

\section{Authors' contribution}

SM; the concept design, literature review, manuscript preparation, and final revision. YA; the concept design, literature review, manuscript review, and final revision. $\mathrm{RD}$; the concept design, literature review, manuscript review, and final revision. All authors read and signed the final paper.

\section{Conflicts of interest}

None.

\section{Ethical considerations}

Ethical issues (including plagiarism, data fabrication, double publication) have been completely observed by the authors.

\section{Funding/Support}

None.

\section{References}

1. Boucher C, Sandford F. Autosomal dominant polycystic kidney disease (ADPKD, MIM 173900, PKD1 and PKD2 genes, protein products known as polycystin-1 and polycystin-2). Eur J Hum Genet. 2004;12:347-54.

2. Sans-Atxer L, Torra R, Fernández-Llama P. Hypertension in autosomal-dominant polycystic kidney disease (ADPKD). Clin Kidney J. 2013;6:457-63.

3. Ecder T, Schrier RW. Hypertension in autosomal-dominant polycystic kidney disease: early occurrence and unique aspects. J Am Soc Nephrol. 2001;12:194-200.

4. Chapman AB, Devuyst O, Eckardt KU, Gansevoort RT, Harris T, Horie S, et al. Autosomal-dominant polycystic kidney disease (ADPKD): executive summary from a Kidney Disease: Improving Global Outcomes (KDIGO) Controversies Conference. Kidney Int. 2015;88:17-27.

5. Zeier M, Geberth S, Schmidt KG, Mandelbaum A, Ritz E. Elevated blood pressure profile and left ventricular mass in children and young adults with autosomal dominant polycystic kidney disease. J Am Soc Nephrol. 1993;3:1451.

6. de Almeida EA, de Oliveira EI, Lopes JA, Almeida AG, Lopes MG, Prata MM. Ambulatory blood pressure measurement in young normotensive patients with autosomal dominant polycystic kidney disease. Rev Port Cardiol. 2007;26:235-43.

7. Gallagher AR, Germino GG, Somlo S. Molecular advances in autosomal dominant polycystic kidney disease. Adv Chronic Kidney Dis. 2010;17:118-30. doi: 10.1053/j. ackd.2010.01.002.

8. Reed-Gitomer B. Autosomal dominant polycystic kidney disease: genetics, epidemiology, and treatment. Dovepress. 
2014;4:173-83.

9. Chapman AB, Stepniakowski K, Rahbari-Oskoui F. Hypertension in autosomal dominant polycystic disease. Adv Chronic Kidney Dis. 2010;17:153-63.

10. Ma M, Gallagher AR, Somlo S. Ciliary mechanisms of cyst formation in polycystic kidney disease. Cold Spring Harb Perspect Biol. 2017;9(11). pii: a028209. doi: 10.1101/ cshperspect.a028209.

11. Lee SH, Somlo S. Cyst growth, polycystins, and primary cilia in autosomal dominant polycystic kidney disease. Kidney Res Clin Pract. 2014;33:73-8.

12. Chapman AB, Johnson A, Gabow PA, Schrier RW. The reninangiotensin-aldosterone system and autosomal dominant polycystic kidney disease. N Engl J Med. 1990;323:1091-6.

13. Graham PC, Lindop GB. The anatomy of the reninsecreting cell in adult polycystic kidney disease. Kidney Int. 1988;33:1084-90.

14. Eckardt KU, Möllmann M, Neumann R, Brunkhorst R, Burger HU, Lonnemann G, et al. Erythropoietin in polycystic kidneys. J Clin Invest. 1989;84;1160-6.

15. Schmid M, Mann JF, Stein G, Herter M, Nussberger J, Klingbeil A, et al. Natriuresis-pressure relationship in polycystic kidney disease. J Hypertens. 1990;8:277-83.

16. Krishnappa V, Vinod P, Deverakonda D, Raina R. Autosomal dominant polycystic kidney disease and the heart and brain. Cleveland Clinic Journal of Medicine. 2017;84;471-81.

17. Ecder T. Cardiovascular complications in autosomal dominant polycystic kidney disease. Curr Hypertens Rev. 2013;9:2-11.

18. Rahbari-Oskoui F, Williams O, Chapman A. Mechanisms and management of hypertension in autosomal dominant polycystic kidney disease. Nephrol Dial Transplant. 2014;29:2194-201.

19. Wenzel RR. Renal protection in hypertensive patients: selection of antihypertensive therapy. Drugs. 2005;65:29-39.

20. Schrier RW, Abebe KZ, Perrone RD, Torres VE, Braun WE, Steinman TI, et al. Blood pressure in early autosomal dominant polycystic kidney disease. $N$ Engl J Med. 2014;371:2255-66

21. Mitobe M, Yoshida T, Sugiura H, Shiohira S, Shimada K, Nitta K, et al. Clinical effects of calcium channel blockers and renin-angiotensin-aldosterone system inhibitors on changes in the estimated glomerular filtration rate in patients with polycystic kidney disease. Clin Exp Nephrol. 2010;14:573-7. doi: 10.1007/s10157-010-0329-5.

22. Nutahara K, Higashihara E, Horie S, Kamura K, Tsuchiya $\mathrm{K}$, Mochizuki T, et al. Calcium channel blocker versus angiotensin II receptor blocker in autosomal dominant polycystic kidney disease. Nephron Clin Pract. 2005;99:c1823.

23. Ecder T, Edelstein CL, Fick-Brosnahan GM, Johnson AM, Chapman AB, Gabow PA, et al. Diuretics versus angiotensinconverting enzyme inhibitors in autosomal dominant polycystic kidney disease. Am J Nephrol. 2001;21:98-103.

24. Nicholas SB, Vaziri ND, Norris KC. What should be the blood pressure target for patients with chronic kidney disease? Curr Opin Cardiol. 2013;28:439-45.
25. Pei Y, Hwang YH, Conklin J, Sundsbak JL, Heyer CM, Chan $\mathrm{W}$, et al. Imaging-based diagnosis of autosomal dominant polycystic kidney disease. J Am Soc Nephrol. 2014;26:74653.

26. Midgley J, Matthew A, Greenwood CT, Logan A. Effect of reduced dietary sodium on blood pressure: a meta-analysis of randomized controlled trials. JAMA. 1996;275:1590-97.

27. Merta M, Reiterová J, Rysavá R, Tesar V, Závada J, Jáchymová $M$, et al. Role of endothelin and nitric oxide in the pathogenesis of arterial hypertension in autosomal dominant polycystic kidney disease. Physiol Res. 2003;52:433-7.

28. Munemura C, Uemasu J, Kawasaki H. Epidermal growth factor and endothelin in cyst fluid from autosomal dominant polycystic kidney disease cases: possible evidence of heterogeneity in cystogenesis. Am J Kidney Dis. 1994;24: 561-8.

29. Giusti R, Neri M, Angelini D, Carlini A, Fiorini I, Bigongiari $\mathrm{P}$, et al. Plasma concentration of endothelin and arterial pressure in patients with ADPKD. Contrib Nephrol. 1995;115:118-21.

30. Kocyigit I, Eroglu E, Kaynar AS, Kocer D, Kargi S, Zararsiz $\mathrm{G}$, et al. The association of endothelin-1 levels with renal survival in polycystic kidney disease patients. J Nephrol. 2018:1-9.

31. Chapman AB, Torres VE, Perrone RD. The HALT Polycystic Kidney Disease Trials: Design and Implementation. CJASN. 2010;5:102-9.

32. Sweitzer NK. What is an angiotensin converting enzyme inhibitor? Circulation. 2003;108:e16-e18

33. Lande MB, Flynn JT. Treatment of hypertension in children and adolescents. Pediatric Nephrology (Berlin, Germany). 2009;24:1939-49.

34. Akoh JA. Current management of autosomal dominant polycystic kidney disease. World J Nephrol. 2015;4(4):468-9.

35. Torres VE, Abebe KZ, Chapman AB, Schrier RW, Braun WE, Steinman TI, et al. Angiotensin blockade in late autosomal dominant polycystic kidney disease. N Engl J Med. 2014;371:2267-76.

36. Zeltner R, Poliak R, Stiasny B, Schmieder RE, Schulze BD. Renal and cardiac effects of antihypertensive treatment with ramipril vs metoprolol in autosomal dominant polycystic kidney disease. Nephrol Dial Transplant. 2008;23:573-9.

37. Jafar TH, Stark PC, Schmid CH, Strandgaard S, Kamper AL, Maschio G, et al. The effect of angiotensin-convertingenzyme inhibitors on progression of advanced polycystic kidney disease. Kidney Int. 2005;67:265-71.

38. van Dijk MA, Breuning $M H$, Duiser $R$, van Es LA, Westendorp RG. No effect of enalapril on progression in autosomal dominant polycystic kidney disease. Nephrol Dial Transplant. 2003;18:2314-20.

39. Ecder T, Chapman AB, Brosnahan GM, Edelstein CL, Johnson AM, Schrier RW. Effect of antihypertensive therapy on renal function and urinary albumin excretion in hypertensive patients with autosomal dominant polycystic kidney disease. Am J Kidney Dis. 2000;35:427-32.

Copyright $\odot 2019$ The Author(s); Published by Nickan Research Institute. This is an open-access article distributed under the terms of the Creative Commons Attribution License (http://creativecommons.org/licenses/by/4.0), which permits unrestricted use, distribution, and reproduction in any medium, provided the original work is properly cited. 